\title{
Profesor Stanisław Litak (1932-2010) - przyczynek do biografii naukowo-dydaktycznej
}

\author{
Professor Stanisław Litak (1932-2010): \\ A Contribution \\ to a Scientific and Didactic Biography
}

\begin{abstract}
ABSTRAKT
Sylwetka naukowo-dydaktyczna prof. Stanisława Litaka obejmuje znaczqcy obszar badań nad historiq społeczno-religijnq epoki nowożytnej, realizowanq w trakcie wieloletniej pracy zawodowej na Katolickim Uniwersytecie Lubelskim w latach 1961-2005. W trakcie akływności zawodowej prof. Litak współtworzył lubelskie środowisko badaczy struktur Kościoła nowożyłnego i geografii historycznej oraz reprezentował je na forum międzynarodowym. Równorzędna rolę w Jego naukowych zainteresowaniach pełniła historia oświaty epoki przedrozbiorowej, która zaowocowała autorstwem popularnego podręcznika akademickiego o historii wychowania, wykorzystywanego do dziś przez studentów zainteresowanych zagadnieniami historii edukacji. Dualizm pracy naukowej odzwierciedlaja również okoliczności zatrudnienia prof. Litaka zarówno w Instytucie Historii oraz w Instytucie Pedagogiki KUL. Pokłosiem lat pracy sq liczne publikacje naukowe, utrzymane w konwencji przyiętych kierunków badawczych. Nieoceniona pozostaje też spuścizna Profesora w postaci kapitału
\end{abstract}

SLOWA KLUCZOWE Stanisław Litak, historia Kościoła, geografia historyczna, historia szkolnictwa, historia wychowania

\section{KEYWORDS}

Stanisław Litak, history of the Church, historical geography, history of schools, history of education

SPI Vol. 21, 2018/2

ISSN 2450-5358

e-ISSN 2450-5366 DOI: 10.12775/SPI.2018.2.005

Nadesłano: 21.01.2018 Zaakceptowano: 1.01.2018 Artykuły i rozprawy 
ludzkiego - seminarzystów, uczniów naukowych, współpracowników, którzy podejmuja trud kontynuacji obranych przez Niego kierunków badawczych. Profesor Litak wyznaczył standardy w pracy naukowej, które pozostaja godne naśladowania, dał się również poznać jako ciepły, skromny, ale wymagajacy nauczyciel akademicki i kierownik zespołów pracowniczych. Warto podkreślić i docenić Jego zasługi dla humanistyki polskiej, ze względu na wartość merytoryczna prac, które na stałe weszły do historiografii. Pamięć o Nim, jako o człowieku nauki, który niósł ze sobq wartości badawcze i utrzymywał dobre relacje międzyludzkie, zasługuje również na propagowanie w środowiskach akademickich.

\section{ABSTRACT}

The scientific and didactic portrait of Professor Stanisław Litak includes a considerable area of research on the social and religious history of the modern era carried out during the many years of work at the Catholic University of Lublin in the years 1961-2005. In the period of his professional activity, Professor Litak co-created the Lublin environment of researchers dealing with the structures of the modern Church and historical geography and he represented it on the international forum. A parallel role in his scientific interests was played by the history of education of the pre-partitioning period. The fruit of those interests was a popular academic textbook written by him about the history of education and still used by students concerned with the issues referring to the history of education. The duality of research work is also reflected in the circumstances in which Professor Litak was employed both at the Institute of History and the Institute of Pedagogy of the Catholic University of Lublin. The aftermath of his work includes numerous scientific publications written within the convention of the adopted scientific research directions. The Professor's legacy in the form of human capital, namely students from the seminar, scientific students and colleagues who undertake the effort to continue the research directions established by him, remains invaluable. Professor Litak established standards in research work which deserve to be followed. He was also known as a warm, modest but demanding university teacher and head of teams. What should be emphasized and appreciated are his merits for the Polish humanities, which are due to the value of his works, constituting a permanent element of historiography. Memory about him as a man of science who epitomized research values and maintained good human relationships also deserves to be kept alive in academic circles. 


\section{Droga kariery zawodowej}

Stanisław Litak urodził się w niewielkiej podkarpackiej miejscowości Glinik (ówczesny powiat dębicki) 23 lutego 1932 roku. Do szkoły podstawowej uczęszczał w pobliskim Wielopolu Skrzyńskim, do szkoły średniej - w Ropczycach, którą ukończył złożeniem egzaminu maturalnego w 1951 roku. Zanim podją studia w Lublinie, pracował przez rok jako wychowawca internatu, w konsekwencji niedostania się na studia na Uniwersytet Jagielloński. Trzeba podkreślić, że lata dzieciństwa i młodości przypadły na ciężkie i trudne czasy historyczne lat wojennych i powojennych, spotęgowane jeszcze osobistą sytuacją rodzinną. Przedwczesna śmierć ojca i niedostatek w domu zahartowały młodego Stanisława, nauczyły pracowitości, konsekwencji i uporu w dążeniu do celu, które to cechy ujawniły się później w toku pracy naukowej. Dzięki pomocy zaprzyjaźnionego kapłana, ks. Michała Siewierskiego, mogła w 1952 roku rozpocząć się Jego studencka przygoda uniwersytecka, zakończona uzyskaniem stopnia magistra historii w 1956 roku na podstawie pracy Rozwój sieci parafialnej w archidiakonacie radomskim w średniowiecz $u^{1}$ (promotor: Jerzy Kłoczowski). Ukończenie studiów było niewątpliwym sukcesem i awansem dla wychowanka wsi, który musiał ciężko pracować, aby utrzymać się na studiach. Jak sam wielokrotnie powtarzał $\mathrm{w}$ osobistych opowieściach, wykonywał w tym czasie wiele prac fizycznych - rozładunek węgla, pomoc w stołówce studenckiej, prace polowe i budowlane na terenach uniwersyteckich, jednocześnie pilnie zgłębiając tajemnice nauki historycznej.

Stanisław Litak na stałe związał się zawodowo z Katolickim Uniwersytetem Lubelskim i jako pracownik etatowy (1961-2005) przepracował tu 45 lat (rok 2005/2006 w ramach umowy o dzieło), łącząc czasowo zatrudnienie w dwóch jednostkach naukowych - Wydziale Nauk Humanistycznych i Wydziale Nauk Społecznych². Wcześniej,

1 M. Surdacki, Profesor Stanistaw Litak - bistoryk Kościota, wychowania i szkolnictwa, w: Religie - edukacja - kultura. Ksiegga Pamiatkowa dedykowana Profesorowi Stanistawowi Litakowi, red. M. Surdacki, Lublin 2002, s. 7.

2 Na Wydziale Nauk Humanistycznych pracował: w latach 1961-1963 w Katedrze Historii Średniowiecznej (Sekcja Historii), w latach 1963-1972 w Katedrze Historii Kultury Polskiej (Sekcja Historii), w latach 19721984 - w Katedrze Historii Szkolnictwa i Wychowania (Sekcja Historii), 
w latach 1956-1961 pracował jako asystent w Instytucie Geografii Historycznej Kościoła w Polsce przy Towarzystwie Naukowym KUL, ze środowiskiem tym pozostając w łączności i w dalszych latach. Przez okres zatrudnienia w KUL zdobywał szczeble kolejnych stopni i tytułów naukowych. W 1963 roku uzyskał na UMCS tytuł doktora nauk humanistycznych na podstawie pracy Osadnictwo iformowanie się sieci parafialnej w Eukowskiem do końca XVI wieku (promotor: Kazimierz Myśliński), a w 1970 roku na Uniwersytecie Warszawskim - stopień doktora habilitowanego nauk humanistycznych w zakresie historii nowożytnej Polski na podstawie pracy Struktura ifunkcje parafii w Polsce od końca XVI do XVIII wieku (recenzenci: Stanisław Herbst, Jerzy Kłoczowski, Janusz Tazbir). Zwieńczeniem kariery naukowej był tytuł profesora nadzwyczajnego, uzyskany w 1983 roku w oparciu o recenzje dorobku naukowego autorstwa Władysława Pałuckiego, Janusza Tazbira, Jerzego Wiśniewskiego i Jerzego Kłoczowskiego, oraz profesora zwyczajnego w 1992 roku.

\section{Zainteresowania badawcze}

Stanisław Litak jako wieloletni współpracownik Instytutu (obecnie Ośrodka) Geografii Historycznej Kościoła w Polsce współtworzył zespół ${ }^{3}$ skupiony wokół przedsięwzięć kartograficznych - „Polonia Christiana” oraz „Atlas Chrześcijaństwa w Europie Środkowo-Wschodniej”. Prace badawcze prowadzone w ramach zespołu prof. Jerzego Kłoczowskiego skrystalizowały się w Jego

w latach 2000-2005 - w Katedrze Dydaktyki Historii i Historii Szkolnictwa (Instytut Historii), a na Wydziale Nauk Społecznych: w latach 1984-2000 w Katedrze Historii Wychowania (Sekcja, od 1996 r. Instytut Pedagogiki). Zob. B. Szady, Litak Stanistaw, w: Encyklopedia 100-lecia KUL (w druku).

3 Instytut Geografii Historycznej Kościoła w Polsce (od 1968 roku przy KUL) powołano na mocy uchwał Towarzystwa Naukowego KUL w 1957 roku. Do jego zarządu weszli: doc. dr Jerzy Kłoczowski (kierownik), dr Marzena Pollakówna (zastępca), doc. dr Zygmunt Sułowski (kierownik Pracowni) i mgr Adam Chruszczewski (sekretarz). Do zespołu badawczego weszli magistrzy historii z seminarium Jerzego Kłoczowskiego, którzy wykonywali prace zlecone do „Atlasu Kościoła w Polsce”: A. Chruszczewski, H. Grocholski, S. Jop, S. Litak, H. Wójcik (Mierkowska), R. Zarzycki. Prace zlecone prowadzili też: dr L. Bieńkowski i mgr E. Wiśniowski. Zob. Wstęp, w: S. Litak, Atlas Kościota tacińskiego w Rzeczypospolitej Obojga Narodów w XVIII wieku, Lublin 2006, s. 14. 
indywidualnych opracowaniach dotyczących organizacji terytorialnej wspólnot religijnych w Rzeczypospolitej Obojga Narodów w okresie nowożytnym. Prace te są punktem wyjścia dla każdego kolejnego badacza struktur parafialnych epoki przedrozbiorowej: Struktura terytorialna Kościota tacińskiego w Polsce w 1772 r. (Lublin 1980), Kościót tacinski w Rzeczypospolitej okoto 1772 roku. Struktury administracyjne (Lublin 1996) oraz Atlas Kościota tacińskiego w Rzeczypospolitej Obojga Narodów w XVIII wieku (Lublin 2006). Obok badań geograficzno-historycznych prof. Litak podejmował w kolejnych pracach również studia nad organizacją i społecznymi funkcjami parafii w okresie nowożytnym (Struktura i funkcje parafii w Polsce, w: Kościót w Polsce, t. 2, red. J. Kłoczowski, Kraków 1968, s. 259-481; Parafie w Rzeczypospolitej w XVI-XVIII wieku. Struktura, funkcje spoteczno-religijne i edukacyjne, Lublin 2004). Monumentalne prace geograficzno-historyczne były wynikiem własnych studiów naukowych, jak również zespołowych. Prof. Litak w ramach tych ostatnich kierował następującymi zespołami badawczymi: w latach 1997-2000: „Mniejszości religijne i narodowe w Rzeczypospolitej w II połowie XVIII wieku" (Instytut Zachodni im. Zygmunta Wojciechowskiego w Poznaniu) oraz w latach 2003-2006: „Atlas religii i wyznań przed I rozbiorem Rzeczypospolitej ok. 1772 r.” (Instytut Europy Środkowo-Wschodniej w Lublinie). Szczegółowa analiza spraw związanych z historią Kościoła znalazła się z kolei w podręcznikowej monografii Od Reformacji do Oświecenia. Kościót katolicki w Polsce nowożytnej (Lublin 1994), a w nurcie metodologii badań nad źródłami kościelnymi epoki staropolskiej podstawowe znaczenie ma Jego publikacja Akta wizytacji parafi z XVI-XVIII wieku jako źródto historyczne, „Zeszyty Naukowe KUL” 5 (1962), nr 3, s. 41-58. Z zakresu edytorstwa źródłowego ukazały się też w opracowaniu prof. Litaka Akta wizytacji generalnej diecezji inflanckiej i kurlandzkiej, czyli piltyńskiej z 1761 roku (Toruń 1998), będące swoistego rodzaju upowszechnieniem w obiegu naukowym tego typu źródła.

W czasie pracy naukowo-badawczej prof. Stanisław Litak prowadził kwerendy w archiwach krajowych i zagranicznych, doskonaląc warsztat historyczny. Wielokrotnie przebywał na stażach i wyjazdach archiwalnych we Włoszech, Holandii, Anglii, Belgii, Niemczech, Francji, Austrii, Izraelu, Litwie, USA. Utrzymywał też łączność z międzynarodowym środowiskiem geografów historycznych 
w ramach konferencji i seminariów naukowych, zwłaszcza w trakcie prac Międzynarodowej Komisji Historii Porównawczej Kościołów (CIHEC), Komisji Historii Porównawczej Kościołów przy Komitecie Nauk Historycznych PAN oraz Komisji Geografii Historycznej przy Komitecie Nauk Historycznych PAN. W 1997 roku został doceniony w tej dziedzinie pracy badawczej na forum ministerialnym, uzyskawszy indywidualną nagrodę Ministra Edukacji Narodowej za wspomnianą wyżej pracę Kościót taciński w Rzeczypospolitej okoto 1772 roku. Struktury administracyjne. Jego prace z zakresu historii Kościoła stanowią do dziś cenną podstawę badań nad historią struktur kościelnych w Rzeczypospolitej przedrozbiorowej.

Jednocześnie prof. Litak poruszał w swoich pracach tematy z zakresu szkolnictwa parafialnego i zakonnego, w tym sprawy edukacji jezuickiej i dzieje KEN. Wieloletnie prace archiwalne nad instytucjami parafialnymi dały, obok publikacji tematycznych, postawę do opracowań kartograficznych odnoszących się do spraw szkolnictwa. Mapy placówek szkolnych weszły m.in. do syntezy Chrześcijaństwo $w$ Polsce ${ }^{4}$. Wszystkim zainteresowanym sprawami historii szkolnictwa służy do dziś, najważniejsze w dorobku oświatowym prof. Litaka, syntetyczne ujęcie dziejów szkolnictwa i wychowania w formie podręcznika akademickiego Historia wychowania, t. 1: Do Wielkiej Rewolucji Francuskiej, Kraków 2004 (do 2010 roku ukazały się jeszcze dwa wydania oraz dodruki). Powstanie podręcznika podyktowane było brakiem aktualnego opracowania dziejów szkolnictwa, przez co studenci kierunków humanistycznych skazani byli na korzystanie z klasycznego, aczkolwiek przestarzałego przedwojennego podręcznika do historii wychowania autorstwa Stanisława Kota lub opracowań powstałych w czasach PRL. Do celów edukacyjnych przystosował więc prof. Litak swoje wykłady z tej tematyki, nadając im charakter syntetyzujący, przedstawiony na szerokim tle społeczno-politycznym, pokazując odbiorcom podręcznika, że historia wychowania jest częścią historii kultury, z której czerpie się wzorce i wartości przekazywane młodemu pokoleniu. Swój podręcznik zadedykował studentom

4 W tym: Szkoły Komisji Edukacji Narodowej w latach 1783-1791; Ważniejsze ośrodki szkolne około 1772 roku; L. Bieńkowski, Oświecenie i katastrofa rozbiorów (2 pot. XVIII w.), w: Chrześcijaństwo w Polsce. Zarys przemian. 966-1979, red. J. Kłoczowski, Lublin 1992, s. 314, 325. 
historii i pedagogiki ${ }^{5}$, aby ukazać historyczny kontekst współczesnej pedagogiki, która czerpie z dorobku myśli pedagogicznej minionych pokoleń. Podręcznik ten, uzupełniony przez kolejny tom autorstwa Jana Drausa i Ryszarda Terleckiego Historia wychowania, t. 2: Wiek XIX i XX, Kraków 2005, stanowi do dziś spójną i jednolitą syntezę historii wychowania od starożytności do początków XXI wieku' Należy podkreślić, że wydanie tego cennego opracowania zostało sfinalizowane przez krakowskie Wydawnictwo Apostolstwa Modlitwy, jako wyraz wieloletniej współpracy i wymiany myśli naukowej miedzy Stanisławem Litakiem a ks. prof. Ludwikiem Grzebieniem ${ }^{7}$.

Niezwykle ważna w perspektywie badań nad historią oświaty była zainicjowana w 1998 roku przez Stanisława Litaka seria wydawnicza „Prace z Historii Szkolnictwa w Polsce”, wydawana przez Towarzystwo Naukowe KUL (do 2009 roku ukazało się 17 tomów). Wydawnictwo to zbiera w jednym cyklu prace monograficzne z zakresu historii społecznej, w tym szkolnictwa i wychowania. Zgodnie z założeniem, łącznikiem cyklu miał być tu szeroki zakres tematyczny, bez względu na okoliczności chronologiczne, a jedynym wymogiem miał być wysoki poziom prac $^{8}$. Poziom ten zapewniany był przez opiekę merytoryczną redaktora serii i obejmował zagadnienie społeczne i szkolne z zakresu szkolnictwa parafialnego, zakonnego, państwowego czy uniwersyteckiego. Seria ta, pod zmienionym tytułem „Prace z Dziejów Szkolnictwa i Opieki Społecznej w Polsce”, jest

5 Z racji nawiązania do podręcznika Stanisława Kota oraz koloru okładki, nazywany przez studentów „niebieskim Kotem”. Zob. A. Puszka, J. Szady, Profesor Stanistaw Litak w Instytucie Historii KUL (1961-2005), w: Vir honestus ac bonus. Stanistaw Litak 1932-2010, red. P.P. Gach, M. Surdacki, Lublin 2011, s. 33.

6 Przedmowa do III wydania, w: S. Litak, Historia Wychowania, t. 1: Do Wielkiej Rewolucji Francuskiej, wyd. III poszerzone i uzupełnione, Kraków 2010, s. 11.

7 Ks. prof. Ludwik Grzebień jest autorem opracowania redakcyjnego, przygotowania glos marginalnych i ilustracji w podręczniku; mapy przygotowała Maria Juran, wieloletnia współpracowniczka prof. Litaka w dziedzinie kartografii. Zob. L. Grzebień, Wspomnienie o przyjacielu i wspótpracowniku, w: Vir honestus ac bonus. Stanistaw Litak 1932-2010, dz. cyt., s. 90; J. Draus, Pamięci Profesora Stanistawa Litaka, w: Vir honestus ac bonus. Stanistaw Litak 1932-2010, dz. cyt., s. 63.

8 J. Miąso, „Prace z historii szkolnictwa w Polsce”, pod red. Stanistawa Litaka, Lublin 1998 [recenzja], „Rozprawy z Dziejów Oświaty” 2005, t. 44, s. 211. 
kontynuowana od 2010 roku przez prof. Mariana Surdackiego. Już po śmierci prof. Litaka, jako pierwsze z nowej serii, ukazało się Jego ostatnie, monograficzne opracowanie na temat dziejów szkolnictwa elementarnego: Edukacja poczatkowa w polskich szkotach w XIII-XVII wieku (Lublin 2010). Seria poszerzyła pierwotny edukacyjny zakres badawczy o działalność opiekuńczo-wychowawczą i społeczną ${ }^{9}$ Uzupełnia ona tym samym pierwotny zamysł wydawniczy o nowe aspekty badawcze i stanowi źródło wiedzy o wartych opracowania inicjatywach wychowawczo-dobroczynnych podejmowanych na przestrzeni wieków (do 2018 roku ukazało się kilkanaście nowych tomów). Prof. Stanisław Litak działał również jako ekspert w dziedzinie współczesnego systemu szkolnictwa. Od 1996 roku był rzeczoznawcą MEN do wydawania opinii kwalifikujących podręczniki do użytku szkolnego. Zrecenzował na potrzeby ministerialne ponad 25 podręczników do nauki historii na różnych szczeblach szkolnych ${ }^{10}$. W 2002 roku uzyskał za zasługi dla oświaty i wychowania Medal Komisji Edukacji Narodowej.

Bibliografia prac prof. Litaka obejmuje blisko 300 pozycji, w tym są również publikacje międzynarodowe: niemieckie, francuskie, włoskie i angielskie ${ }^{11}$. Wśród nich odnajdujemy m.in. opracowania syntetyzujące, monograficzne, encyklopedyczne, przyczynkowo-przeglądowe, polemiczne czy w formie komunikatów. Ich autor jawi się na tle panoramy tematów i form wydawniczych jako znawca metodyki pracy badawczej na podstawie akt wizytacji kościelnych i erudyta w kwestii tematyki struktur administracyjnych Kościoła, osadnictwa, zagadnień wyznaniowo-religijnych i kulturowych epoki nowożytnej w szerokim ujęciu geograficznym. Od połowy lat 70 . uwadze wydawniczej badacza podlegały też zagadnienia szkolnictwa staropolskiego, wynikające z naturalnej łączności ich ze środowiskiem

9 M. Surdacki, Od Redaktora serii, w: S. Litak, Edukacja poczatkowa w polskich szkotach w XIII-XVIII wieku, Lublin 2011, s. 5. (Prace z Dziejów Szkolnictwa i Opieki Społecznej w Polsce, t. 1, red. M. Surdacki).

10 Wykaz recenzowanych podręczników, oprac. J. Szady, w: Vir honestus ac bonus. Stanistaw Litak 1932-2010, dz. cyt., s. 265-266.

11 Bibliografia prac Stanistawa Litaka za lata 1958-2001, oprac. T. Litak, w: M. Surdacki, Profesor Stanistaw Litak - historyk Kościota, wychowania i szkolnictwa, dz. cyt., s. 743-766; Bibliografia prac Stanistawa Litaka za lata 19582010, oprac. T. Litak (za lata 1958-2002) i J. Szady (za lata 2003-2010), w: Vir honestus ac bonus. Stanistaw Litak 1932-2010, dz. cyt., s. 227-251. 
duchowieństwa parafialnego i zakonnego, opisywanego w pracach z zakresu historii Kościoła nowożytnego. Szerokie spektrum badawcze rozwijane było $\mathrm{w}$ trakcie seminarium magisterskiego i doktoranckiego, co zaowocowało w latach $1974-2008$ ponad 150 pracami młodych adeptów nauk historycznych ${ }^{12}$. Ocena i polemika $z$ tezami naukowymi podejmowana była też w licznych recenzjach prac doktorskich, habilitacyjnych oraz profesorskich.

\section{Człowiek - mistrz - wychowawca}

Praca w środowisku uniwersyteckim umożliwiła Stanisławowi Litakowi kontakt nie tylko ze słowem pisanym w formie źródeł i opracowań naukowych, ale też i z ludźmi nauki - kadrą naukową, administracyjną oraz liczną grupą studentów. W trakcie swojej pracy zawodowej prof. Litak pełnił wiele funkcji administracyjnych, kilkukrotnie był kierownikiem Sekcji Historii (w latach 1971-1972, 1973-1974, 1977-1979, 1980-1981), a oprócz kierowania katedrami zajmującymi się sprawami szkolnictwa i wychowania na dwóch wydziałach był też kuratorem Katedry Historii Szkolnictwa w Sekcji (Instytucie) Historii w latach 1985-2000 ${ }^{13}$. Zaangażowanie prof. Litaka w pracę na dwóch wydziałach zbiegło się ze zmianami w strukturze organizacyjnej KUL, kiedy reaktywowano Sekcję Pedagogiki w 1984 roku (zlikwidowaną przez władze państwowe w roku 1949). Kierownictwo od 1972 roku Katedry Historii Szkolnictwa i Wychowania, przeniesionej ze zlikwidowanej Sekcji Pedagogiki, było czynnikiem łączącym od tej pory pion szkolno-wychowawczy na obu wydziałach ${ }^{14}$. Dualizm pracy etatowej harmonizował też z wielokierunkowością zainteresowań badawczych prof. Litaka, zogniskowanych wokół zagadnień geografii historycznej, historii Kościoła, szkolnictwa i wychowania.

$\mathrm{Z}$ racji specjalizowania się w historii nowożytnej Stanisław Litak prowadził zajęcia $\mathrm{z}$ tej epoki dla studentów historii, w tym wykłady

12 Prace magisterskie i doktorskie napisane pod kierunkiem profesora Stanistawa Litaka, oprac. T. Litak (za lata 1974-2002), J. Szady (za lata 2003-2008), w: Vir honestus ac bonus. Stanistaw Litak 1932-2010, dz. cyt., s. 253-262.

13 B. Szady, Litak Stanistaw, dz. cyt.

14 Sekcja Historii: Katedra Historii Szkolnictwa, oprac. W. Matwiejczyk, w: Księga Pamiatkorwa w 75-lecie Katolickiego Uniwersytetu Lubelskiego. Wktad w kulture polskq w latach 1968-1993, red. M. Rusecki, Lublin 1994, s. 294. 
odnoszące się do problemów polityki wewnętrznej państwa polskiego i przemian społeczno-politycznych w czasach staropolskich.

Nadzorował również organizację i funkcjonowanie programu specjalizacji nauczycielskiej w Instytucie Historii, prowadząc dla studentów II roku specjalizacji wykład z historii wychowania (na IV roku studiów magisterskich) ${ }^{15}$. Nade wszystko propagował wiedzę i warsztat historyczny na seminarium magisterskim z zakresu historii Kościoła, szkolnictwa i wychowania, czyli w kierunkach dominujących w Jego pracy naukowej. Wysoki poziom prac, solidna podstawa źródłowa i dociekliwa metoda analityczna, procentowały później możliwością kontynuacji podjętych wówczas badań na seminarium doktoranckim, otwierały też drogę do naukowej pracy badawczej. Podsumowaniem wieloletnich dokonań naukowo-dydaktycznych był jubileusz 40-lecia pracy naukowej uczczony wydaniem okolicznościowej księgi pamiątkowej: Religie - edukacja - kultura. Księga pamiatkowa dedykowana Profesorowi Stanistawowi Litakowi, red. M. Surdacki, Lublin 2002. Uczniowie, przyjaciele i koledzy, spotkani na ścieżkach kariery zawodowej, przygotowali do niej 70 artykułów naukowych jako dowód uznania dla osiągnięć Jubilata.

Prof. Stanisław Litak doczekał się jeszcze drugiej, pośmiertnej księgi pamiątkowej, o charakterze wspomnieniowym, która jest zapisem wzruszających, osobistych relacji osób z nim związanych: z kręgu rodziny, współpracowników, znajomych i uczniów naukowych. Książka Vir honestus ac bonus. Stanistaw Litak 1932-2010, red. P.P. Gach, M. Surdacki, Lublin 2011 zawiera szereg zapisów z rozmów, konsultacji, spotkań z prof. Litakiem na różnych etapach Jego życia. Czytelnik uzyskuje po lekturze tej książki złożony obraz człowieka - rodzica, przyjaciela, przełożonego i mistrza. Jest to zaskakująca lektura dla samych autorów wspomnień, bo widzimy w nich wzajemnie uzupełniające się relacje. Różne migawki z życia prof. Litaka mają jednak wspólny mianownik w ocenie bohatera tej książki. Każdy piszący podkreśla takie cechy profesora, jak rzetelność, skrupulatność badań, pracowitość i kulturę osobistą, stale obecne w jego życiu i działalności, co świadczy o całościowej charakterystyce, nie

15 A. Puszka, J. Szady, Profesor Stanistaw Litak w Instytucie Historii KUL (1961-2005), w: Vir honestus ac bonus. Stanistaw Litak 1932-2010, dz. cyt., s. 32 . 
tylko epizodycznych zachowaniach Stanisława Litaka ${ }^{16}$. Jest to też przekaz o słabościach ludzkich, jakimi była wieloletnia choroba, okoliczności pożegnania się z pracowitym życiem czy konfrontacja z realiami życia w czasach PRL. Praca zawodowa od lat 80. była, jak się okazuje, znacznie utrudniona przez skutki przebytej za granicą ciężkiej choroby i kilku operacji, po których profesor nigdy nie odzyskał pełni sił $^{17}$. Oparciem była dla Niego troskliwa opieka żony Teresy, którą poznał w trakcie studiów, i miłość dzieci. Pozwoliło mu to przetrwać trudne chwile związane $\mathrm{z}$ nagonką na Jego osobę, kiedy oczekiwania społeczne prowokowały do rozliczenia się z okresem PRL i wyjaśnienia związków ze Służbą Bezpieczeństwa ${ }^{18}$. Sprawy te podjął prof. Litak w autobiograficznym tekście opisującym rzeczywistość 1963 roku: staranie się o paszport, przesłuchanie i fakt zarejestrowania ${ }^{19}$. Sprawa ta miała w zasadzie typowy przebieg operacyjny, podejmowany w okolicznościach starań naukowców o uzyskanie paszportu potrzebnego do wyjazdu zagranicznego. Jak ważny był to dla Niego tekst, stanowiący świadectwo czasów i zachowań ludzkich wobec struktur aparatu bezpieczeństwa, dowiedzieliśmy się dopiero po Jego śmierci. Nie zachowały się żadne dokumenty, które potwierdzałyby zmaterializowanie się wspomnianej rejestracji w postaci doniesień agenturalnych. Sprawę inwigilacji całego środowiska historyków KUL podjęto w ostatnich latach w osobnej publikacji, która potwierdza fakt zarejestrowania Stanisława Litaka jako TW "Adam” z jednoczesnym zaznaczeniem wycofania się z nieudanego werbunku rok później ${ }^{20}$. Nadmienić trzeba, że aż do lat 80. prof. Litak konsekwentnie unikał angażowania się w działalność polityczną. Przełamał swoją postawę dopiero w momencie tworzenia się struktur

16 Dodatkową okazją do wspomnień była uroczystość promocji książki połączona ze spotkaniem poświęconym śp. Profesorowi Stanisławowi Litakowi w dniu 26 maja 2011 roku w Instytucie Historii KUL.

17 A. Litak-Ścibior, Życie poświęcit nam, uczniom i Uniwersytetowi, w: Vir honestus ac bonus. Stanistaw Litak 1932-2010, dz. cyt., s. 47.

18 M. Litak-Pietroń, Mój Tato, w: Vir honestus ac bonus. Stanistaw Litak 19322010, dz. cyt., s. 39.

19 S. Litak, Moje potyczki z „wtadza ludowa”, w: Przestrzeń wolności i prawdy. Katolicki Uniwersytet Lubelski w latach 1944-1989, red. J.F. Fert, Lublin 2008, s. 115-116.

20 M. Sobieraj, Między oporem a lojalnościq. Dziatania SB wobec KUL na przyktadzie rozpracowania prof. Jerzego Ktoczowskiego, Lublin 2015, s. 289. 
NSZZ „Solidarność” na uczelni, m.in. znalazł się w grupie delegatów na zjazdy „Solidarności” środowisk naukowych ${ }^{21}$.

Każdy, kto zetknął się osobiście z prof. Litakiem lub tylko z Jego publikacjami, tworzy płaszczyznę przenoszącą dorobek myśli naukowo-dydaktycznej na dalsze obszary. Materialna spuścizna naukowa prof. Litaka stanowi nadal podstawę warsztatu badawczego historyków KUL. Zgodnie z Jego życzeniem, książki, mapy, rękopisy, wypisy źródłowe i mikrofilmy zostały przekazane do Instytutu Historii KUL z przeznaczeniem do dalszych badań22. Ważny jednak jest też krąg uczniów, podejmujących naukowy trud w kierunkach badawczych zapoczątkowanych przez prof. Litaka. Pomimo wielkiego zaangażowania $\mathrm{w}$ pracę naukową, nie wszystkie pomysły zdążył zrealizować, w tym m.in. opracowanie dziejów szkół zakonnych, które pierwotnie miało być częścią dwutomowej pracy o szkolnictwie przedrozbiorowym $^{23}$. Wśród Jego licznych projektów czeka obecnie na realizację Atlas wyznań i religii w Rzeczypospolitej ok. 1772 r., przygotowywany z wykorzystaniem najnowszych możliwości technologicznych ${ }^{24}$.

\section{Bibliografia}

Bibliografia prac Stanistawa Litaka za lata 1958-2001, oprac. T. Litak, w: M. Surdacki, Profesor Stanistaw Litak - bistoryk Kościota, wychowania i szkolnictwa, w: Religie - edukacja - kultura. Ksiega Pamiątkowa dedykowana Profesorowi Stanistawowi Litakowi, red. M. Surdacki, Towarzystwo Naukowe KUL, Lublin 2002, s. 743-766.

Bibliografia prac Stanistawa Litaka za lata 1958-2010, oprac. T. Litak (za lata 1958-2002) i J. Szady (za lata 2003-2010), w: Vir honestus ac bonus. Stanistaw Litak 1932-2010, red. P.P. Gach, M. Surdacki, Towarzystwo Naukowe KUL, Lublin 2011, s. 227-251.

Bieńkowski L., Oświecenie i katastrofa rozbiorów (2 pot. XVIII w.), w: Chrześcijaństwo w Polsce. Zarys przemian. 966-1979, red. J. Kłoczowski, Towarzystwo Naukowe KUL, Lublin 1992, s. 295-372.

„Solidarnośc" na KUL-u, cz. 1: W okresie od 18 września 1980 do 4 marca 1988 r., oprac. E. Jabłońska-Deptuła, w: Ksiegga Pamiątkowa w 75-lecie Katolickiego Uniwersytetu Lubelskiego. Wktad w kulture polskq w latach 1968-1993, dz. cyt., s. 776.

22 J. Szady, Profesor Stanistaw Litak historyk Kościota, szkolnictwa i wychowania (1932-2010), „Teka Komisji Historycznej - OL PAN” 2011, t. 8, s. 238.

23 Postowie, w: S. Litak, Edukacja początkowa w polskich szkotach w XIII-XVIII wieku, Lublin 2011, s. 279.

24 Pracownia Geoinformacji Historycznej KUL, http://hgis.kul.pl/projekty/ [dostęp: 9.01.2018]. 
Draus J., Pamięci Profesora Stanistawa Litaka, w: Vir honestus ac bonus. Stanistaw Litak 1932-2010, red. P.P. Gach, M. Surdacki, Towarzystwo Naukowe KUL, Lublin 2011, s. 62-65.

Grzebień L., Wspomnienie o przyjacielu i wspótpracowniku, w: Vir honestus ac bonus. Stanistaw Litak 1932-2010, red. P.P. Gach, M. Surdacki, Towarzystwo Naukowe KUL, Lublin 2011, s. 88-90.

Litak S., Moje potyczki z „wtadzq ludowa”, w: Przestrzeń wolności i prawdy. Katolicki Uniwersytet Lubelski w latach 1944-1989, red. J.F. Fert, Wydawnictwo KUL, Lublin 2008, s. 113-123.

Litak-Pietroń M., Mój Tato, w: Vir honestus ac bonus. Stanistaw Litak 19322010, red. P.P. Gach, M. Surdacki, Towarzystwo Naukowe KUL, Lublin 2011, s. 39-45.

Litak-Ścibior A., Życie poświęcit nam, uczniom i Uniwersytetowi, w: Vir honestus ac bonus. Stanistaw Litak 1932-2010, red. P.P. Gach, M. Surdacki, Towarzystwo Naukowe KUL, Lublin 2011, s. 46-49.

Miąso J., „Prace z historii szkolnictwa w Polsce”, pod red. Stanistawa Litaka, Lublin 1998, [recenzja], „Rozprawy z Dziejów Oświaty” 2005, t. 44, s. 211-216.

Postowie, w: S. Litak, Edukacja poczatkowa w polskich szkotach w XIII-XVIII wieku, Towarzystwo Naukowe KUL, Lublin 2011, s. 279.

Prace magisterskie i doktorskie napisane pod kierunkiem profesora Stanistawa Litaka, oprac. T. Litak (za lata 1974-2002), J. Szady (za lata 2003-2008), w: Vir honestus ac bonus. Stanistaw Litak 1932-2010, red. P.P. Gach, M. Surdacki, Towarzystwo Naukowe KUL, Lublin 2011, s. 253-262.

Pracownia Geoinformacji Historycznej KUL, http://hgis.kul.pl/projekty/ [dostęp: 9.01.2018].

Przedmowa do III wydania, w: S. Litak, Historia Wychowania, t. 1: Do Wielkiej Rewolucji Francuskiej, wyd. III poszerzone i uzupełnione, Wydawnictwo WAM, Wyższa Szkoła Filozoficzno-Pedagogiczna „Ignatianum”, Kraków 2010, s. 11.

Puszka A., Szady J., Profesor Stanistaw Litak w Instytucie Historii KUL (1961-2005), w: Vir honestus ac bonus. Stanistaw Litak 1932-2010, red. P.P. Gach, M. Surdacki, Towarzystwo Naukowe KUL, Lublin 2011, s. 31-34.

Sekcja Historii: Katedra Historii Szkolnictwa, oprac. W. Matwiejczyk, w: Ksiega Pamiatkowa w 75-lecie Katolickiego Uniwersytetu Lubelskiego. Wktad w kulture polska w latach 1968-1993, red. M. Rusecki, Redakcja Wydawnictw KUL, Lublin 1994, s. 294.

Sobieraj M., Między oporem a lojalnościq. Dziatania SB wobec KUL na przyktadzie rozpracowania prof. Jerzego Ktoczowskiego, Instytut Pamięci Narodowej, Komisja Ścigania Zbrodni przeciwko Narodowi Polskiemu, Oddział w Lublinie, Lublin 2015.

„Solidarnośc” na KUL-u, cz. 1: W okresie od 18 września 1980 do 4 marca 1988 r., oprac. E. Jabłońska-Deptuła, w: Ksiega Pamiattowa w 75-lecie Katolickiego Uniwersytetu Lubelskiego. Wktad w kulture polska w latach 
1968-1993, red. M. Rusecki, Redakcja Wydawnictw KUL, Lublin 1994, s. 773-780.

Surdacki M., Od Redaktora serii, w: S. Litak, Edukacja poczatkowa w polskich szkotach w XIII-XVIII wieku, Towarzystwo Naukowe KUL, Lublin 2011, s. 5.

Surdacki M., Profesor Stanistaw Litak - historyk Kościoła, wychowania i szkolnictwa, w: Religie - edukacja - kultura. Księga Pamiatkowa dedykowana Profesorowi Stanistawowi Litakowi, red. M. Surdacki, Towarzystwo Naukowe KUL, Lublin 2002, s. 5-14.

Szady B., Litak Stanistaw, w: Encyklopedia 100-lecia KUL (w druku).

Szady J., Profesor Stanistaw Litak historyk Kościota, szkolnictwa i wychowania (1932-2010), „Teka Komisji Historycznej - OL PAN” 2011, t. 8, s. 236-238.

Wstęp, w: S. Litak, Atlas Kościota tacińnkiego w Rzeczypospolitej Obojga Narodów w XVIII wieku, Towarzystwo Naukowe KUL, Lublin 2006, s. 9-29.

Wykaz recenzowanych podręczników, oprac. J. Szady, w: Vir honestus ac bonus. Stanistaw Litak 1932-2010, red. P.P. Gach, M. Surdacki, Towarzystwo Naukowe KUL, Lublin 2011, s. 265-266.

\section{ADRES DO KORESPONDENCJI:}

Dr Joanna Szady

Katolicki Uniwersytet Lubelski Jana Pawła II Instytut Historii

e-mail: szady1@kul.lublin.pl 